\title{
ARCHITECTURE AS POLITICS
}

\section{A B S T R A C T}

The paper presents a comment on Jacques Rancière's thinking on architecture as traced in The Politics of Aesthetics and juxtaposed with a case study $-1^{\text {st }}$ Exhibition of Architecture of the People's Poland. The exhibition organized in the era of Stalinism (1953) and shown in the Central Bureau for Artistic Exhibitions (nowadays the Zachęta - National Gallery of Art in Warsaw) is seen as a manifestation of 'artistic regimes' of the period and as aesthetisation of architecture which is commonly considered the most 'political' of all the (fine) arts. Architecture does not seem to be the main concern of The Politics of Aesthetics; most translators and (Polish) commentators of Rancière's philosophical writings draw our attention to the importance of his aesthetics for the relational aspects of contemporary art in public spaces. The article aims at emphasizing the architectural moments in Rancière's project of aesthetics as politics; it also elaborates a couple of notions poiessis/mimēsis - as discussed by Rancière - in relation to architectural theory and history of architectural exhibitions. 
'In the 1950s Warsaw everybody had an idea of architecture, like in bygone days in Alaska everybody had an idea of gold-digging' - claims Leopold Tyrmand in the legendary Polish detective story Zly [Evil], in which he sketches a superb social and architectural panorama of Warsaw in the first years after the Second World War. ${ }^{1}$ The novelist's irony over what it meant 'to have an idea of architecture' - should be read in the political and historical context of the 1950s Poland, the time of Stalinism. For it was not just the First Secretary of the Polish United Workers' Party who merited the epithet of the 'First Architect of Socialist Realism', but rather 'the whole nation was building our capital'- as proclaimed a series of Polish posters designed in the 1950s. The idea of architecture was also spread through a great number of architectural exhibitions - some thirty-three shows organized in all the regions of Poland in the period 1950-1953.

Let us discuss just one example - the 1st Exhibition of Architecture of the People's Poland (Fig.1) organized in 1953 in the Central Bureau for Artistic Exhibitions (nowadays Zachęta - National Gallery of Art in Warsaw). The exhibition was opened on $8^{\text {th }}$ March; thus, Stalin died three days earlier. It was visited by 50.000 people, including more than a hundred organized groups, ${ }^{2}$ and opening hours were adjusted to the everyday working routines of prospective viewers, with the exhibition open until $9 \mathrm{pm}$. The so-called 'high culture' of the art gallery was to be experienced for free in workers' leisure time; however, in the case of the 1953 Warsaw exhibition, there were no clear borders between high and mass culture. As Jacques Rancière argues, 'an aesthetic community is not a community of aesthetes. It is a community of sense, or a sensus communis'. ${ }^{3}$ The aim of the 1st Exhibition of Architecture of the People's Poland was the popularization of the achievements of Polish socialist architecture 'against the background of past epochs'. ${ }^{4}$ The exhibition presented buildings already constructed or designed between January 1945 and December 1952, juxtaposed with historical objects. In line with this strategy, the exhibition catalogue opened with photographs of the Wawel Royal Castle in Cracow and of Romanesque columns in the church of Strzelno. ${ }^{5}$

The show in the Warsaw Central Bureau consisted of six sections presenting the achievements of six Polish regions: Warsaw (Mazovia), Katowice (between $7^{\text {th }}$ March 1953 and 1956, Stalinogród ${ }^{6}$ ), Wrocław (Upper and Lower Silesia), Gdańsk, Szczecin (Pomerania), Białystok (Podlasie), Łódź, Cracow with Nowa Huta (Lesser Poland), Poznań (Greater Poland). ${ }^{7}$ (Fig. 2) The seventh section, the Hall of Honor was also named 'the hall of Polish-Soviet friendship' with its dominant feature being a large photograph of the model of the Palace of Culture 
and Science (completed in 1955) and other Warsaw projects 'representative of ideological cooperation between Poland and Soviet Union'. ${ }^{8}$ (Fig. 3) The concept of socrealism required architecture which would be socialist in content and national in form. ${ }^{9}$ Therefore, Gdańsk and Pomerania region were considered an appropriate source of northern Renaissance forms, while Warsaw was seen as a city of neoclassicism.(Fig. 4) Having received the regional forms as examples to be followed, architects were expected 'to reject the whole era of eclecticism and cosmopolitism of the $19^{\text {th }}$ century and the interwar period.${ }^{10} \mathrm{In}$ April 1953, the exhibition served as the backdrop for the $1^{\text {st }}$ Polish Council of Architecture with its invited guests -340 delegates from the Soviet Union and other 'democratic' countries. Aleksandr W. Własow, the architect of Moscow - among many other delegates - pointed to the main threats to contemporary architecture. 'Degenerate tendencies' - such as constructivism, or decadent Viennese art nouveau - were the first threat. The second was 'de-urbanism', a concept which promotes our 'escape from the city'. De-urbanism - as Własow explained - 'wants to dismember the urban organism into separate, quasinatural garden-cities'. Contemporary architects should follow Lenin's teaching on the city as 'the best form of human settlement'. ${ }^{11}$

The purpose of this paper is not to discuss the idea of socrealism in Polish architecture; this problem has been well researched in European political history. In recent years, there has been a marked revival of interest in the history of architectural exhibitions; the 1953 Warsaw show serves here as an example of this research field. An exhibition of architecture is, in a sense, a mixed media representation of something that has already been built and of something that does not yet exist as an architectural and urban environment. This kind of multimediality gives us an idea of architecture in the context of an art gallery space. In the Warsaw exhibition catalogue, Roman Piotrowski (a Polish architect active in the interwar period and the Minister of Building of Cities and Housing Estates in the 1950s) emphasizes the social function of architecture exhibitions at the time of the extensive rebuilding of Poland. As he notes:

Architecture works in the most intensive way as a complete building realized in its proper environment. However, its location sometimes limits the scope of its social influence; in order to admire a building a viewer needs to visit the place where it is located. [...] The exhibition is therefore one of the best ways to present architecture to the people. ${ }^{12}$

It might seem a paradox that in order to render 'realism and the social function' of architecture, the exhibition presented twenty-five sculpture-like mock-ups, and more than thousand architectural drawings and photographs. ${ }^{13}$ (Fig. 5) 
In modern systems of arts (crystallized in the aesthetics of such thinkers as, Charles Batteux, Immanuel Kant or James Fergusson) architecture has always oscillated between the status of mechanical and fine art or, to put it another way, it has always had to struggle for the right to a dignified position among fine arts. ${ }^{14}$ Nowadays we accept with ease the definition of architecture as the most social and the most political of all the arts. In other words, architecture's artistic and aesthetic aspects seem less important than its potential to build a community. 'My house is not architecture; it is my home' - symptomatically argues Polish artist Artur Żmijewski in his introduction to the Polish translation of Jacques Rancière's The Politics of Aesthetics. ${ }^{15}$ The opposition of the arts is one of the main points in Rancière's reflection: 'In the [representational] order, what was relevant was the opposition between fine arts - or liberal arts - and mechanical arts, which meant an opposition between arts designed for pleasure and glorification of gentle people and arts designed to respond to the necessities of practical life' ${ }^{16}$ In the context of exhibitions, the practical aspects of architecture seem to be limited by the modalities of representation through the medium of images and models. But, this is not to say that automatically architecture becomes a 'fine' art designed only for pleasure.

Most commentators of Rancière's writings draw our attention to the importance of his aesthetics for its emphasis on the relational or participatory aspects of contemporary art. Architecture as a separate practice does not seem to be the main concern of Rancière's The Politics of Aesthetics; only occasionally does he discuss, for example, the political implications of the British Art \& Crafts movement and its derivatives, such as Art Deco, Werkbund, Bauhaus and Russian Constructivism. ${ }^{17}$ And yet, there are at least two lessons - as Slavoj Žižek recommends in his afterword ${ }^{18}$ - that can be taken from Rancière for our reflection on architecture.

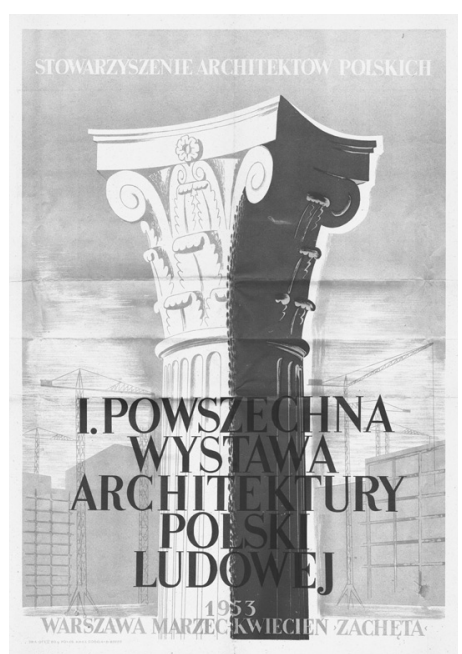

Figure 1. $1^{\text {st }}$ Exhibition of Architecture of the People's Poland, 1953 (poster).

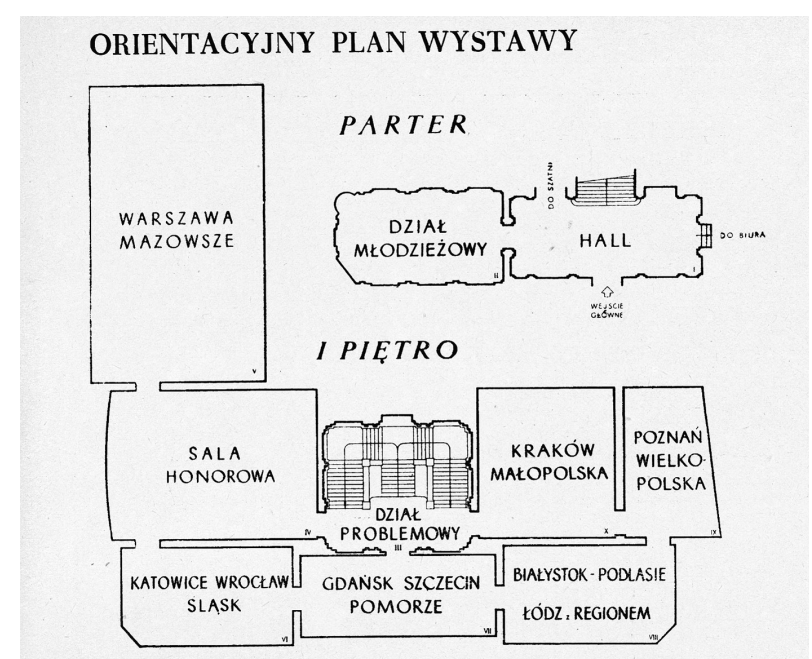

Figure 2. $1^{\text {st }}$ Exhibition of Architecture of the People's Poland, 1953 (plan with six regional sections and the Hall of Honour). 
Undoubtedly, the first lesson that comes from Rancière is his critique of the modern dichotomy between art for art's sake and social reality, or of the aforementioned opposition between the fine and mechanical arts. ${ }^{19}$ Rancière questions this dichotomy, for example, in his essay on design (Surface of Design), where he draws a daring comparison between the symbolist poetry of Stéphane Mallarmé and the work of architect and engineer Peter Behrens. There is no such thing as an 'autonomous' or 'heteronomous' art - Ranciére concludes. ${ }^{20}$ The 'modern aesthetic revolution' abolished the hierarchy in art which used to reflect the prevailing social hierarchy. 'Forms of poems' and forms of industrial (or architectural) objects are forms of life. ${ }^{21}$ Crucial for our understanding of modernity is also Rancière's emphasis of the simple fact that art in the singular has only existed for two centuries. ${ }^{22}$ In line with this thought, one should return to the pre-modern situation in order to see architecture outside the field of the oppositions of 'mechanical' versus 'liberal', but in the realm of mimèsis. As Rancière notes: 'mimēsis is not the law that brings the arts under the yoke of resemblance. It is first of all a fold in the distribution of ways of doing and making as well as in social occupations, a fold that renders the arts visible. It is not an artistic process but a regime of visibility regarding the arts'. ${ }^{23}$ Similarly, some contemporary philosophers and historians of architecture argue that Aristotle's celebrated definition of tragedy as mimessis (representation) of praxis (action) outlines also the main function of architecture. ${ }^{24}$ In this light, there is no point to discuss whether architecture belongs to mechanical or liberal arts. Architecture is the 'representation of action'.

The second lesson which might be taken from Rancière (especially in the context of the 1953 Warsaw exhibition) is his reflection on the revival of the Gesamtkunstwerk in contemporary art. ${ }^{25}$ Rancière uses this notion, for example, with reference to a general confusion of the genres. As he argues:

We have plays without words and dance with words; installations and performances instead of 'plastic' work; video projections turned into cycles of frescoes; photographs turned into living pictures or history paintings; sculpture that becomes hypermediatic show; etc. Now, there are three ways of understanding and practicing this confusion of the genres. There is the revival of the Gesamtkunstwerk, which is supposed to be the apotheosis of art as a form of life but which proves instead to be the apotheosis of strong artistic egos or a kind of hyperactive consumerism, if not of both at the same time. There is the idea of 'hybridization' of the means of art, which complements the view of our age as one of mass individualism expressed through the relentless exchange between roles and identities, reality and virtuality, life and 
mechanical prostheses, and so on. [...] The third way - the best in my view - does not aim at the amplification of the effect but at the transformation of the cause/effect scheme itself [...]. It invalidates the opposition between activity and passivity as well as the scheme of 'equal transmission' and the communitarian idea of the theater that in fact makes it an allegory of inequality. ${ }^{26}$

In the light of this argument, contemporary multimediality is not Gesamtkunstwerk in its $19^{\text {th }}$-century version, with its aesthetic program as a program of metapolitics: 'multimediality only means that you combine several media' ${ }^{27}$ Rancière only occasionally mentions the notion of Gesamtkunstwerk, but often returns to the German Romantic roots of this concept. Central to his reflection is an analysis of Schiller's Letters on the Aesthetic Education of Man (1795) and The Oldest Systematic Program of German Idealism (by Schelling, Hegel and Hölderlin) in which the 'highest act of reason' is identified with an 'aesthetic act'. ${ }^{28}$ The aesthetic program of German Idealism, that is, 'art as the transformation of thought into the sensory experience of the community', according to Rancière, is basic for the writings of the young Karl Marx. ${ }^{29}$ Not accidentally, Rancière also discusses aspects of Adolphe Appia's views on total theater - a theater that might get out of itself and become a form of existence for society itself. ${ }^{30}$ Rancière also traces the project of an 'art which becomes a form of life' in the programs of the Arts and Crafts, Werkbund and Bauhaus with its ideal expressed in the 1919 manifesto: 'The ultimate aim of all visual arts is the complete building! Architects, painters and sculptors must learn to grasp the composite character of a building. Only then will their work be imbued with the architectonic spirit which it has lost as «salon art»' ${ }^{31}$

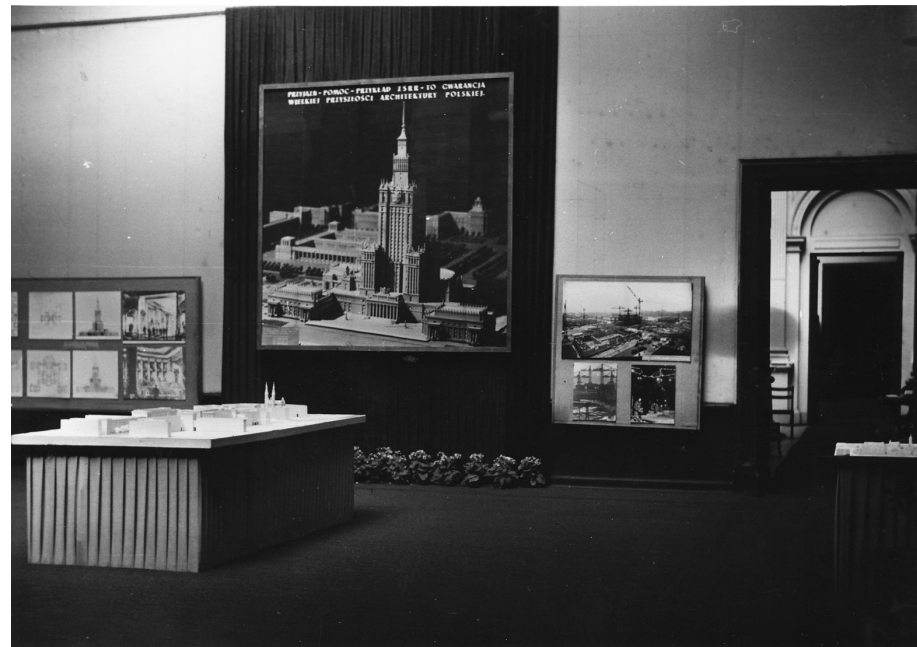

Figure 3. $1^{\text {st }}$ Exhibition of Architecture of the People's Poland, 1953 (Hall of Honour) Photo: Zachęta - National Gallery of Art, Warsaw

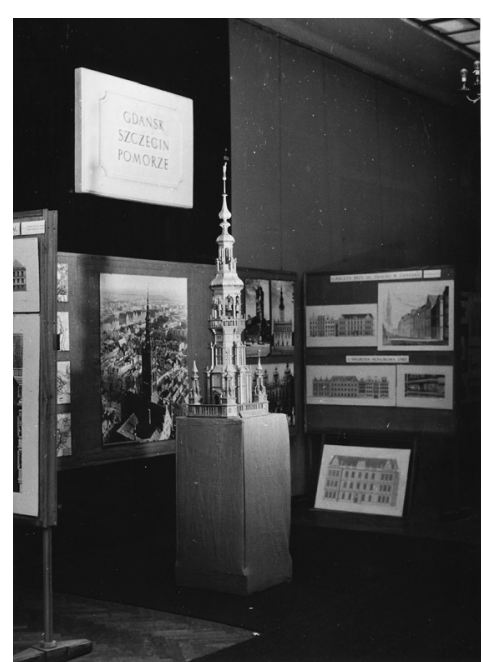

Figure 4. $1^{\text {st }}$ Exhibition of Architecture of the People's Poland, 1953 (Pomerania region). Photo: Zachęta National Gallery of Art, Warsaw 
In the 1953 Warsaw exhibition catalogue we find excerpts from the resolution of the Polish Council of Architects (1949), which provided the foundations for socialist realism. As we read: 'Polish architecture should be reborn as a great social art. [...] New social architecture, through the organic cooperation with painting and sculpture, through the synthesis of the arts will create a rich new plastic art which will oppose the barrenness of constructivism' ${ }^{32}$ What is evident in this quotation - represented in the 1953 exhibition in the form of decorative plaque (Fig. 6) - is an appropriation of the idea of the Gesamtkunstwerk at the time of Stalinism (a problem already discussed in Boris Groys' The Total Art of Stalinism) ${ }^{33}$

I use the word 'appropriation' following Žižek's argument about the lesson of Rancière - that 'one should be careful not to succumb to the liberal temptation of condemning all collective artistic performances as inherently «totalitarian»' ${ }^{34}$ Žižek, for example, talks about stealing the ideas of collective performances (parades, mass performances in stadiums): 'it was Nazism that stole them and appropriated them from the worker's movement, their original site of birth' ${ }^{35}$ The lesson of Rancière in relation to architecture would be therefore to identify the concept of Gesamtkunstwerk (the apotheosis of art/architecture as a form of life) as different 'framings of a specific sensorium'. ${ }^{36}$

The history of the Gesamtkunstwerk is a history of appropriations, or - as I call it, borrowing a notion from music - of 'transcriptions' of the concept, as when a general idea (melody) is orchestrated using different instruments in each performance, while still preserving a recognizable identity. ${ }^{37}$ The most problematic (sometimes superficially labeled 'pre-Fascist' or 'totalitarian') modern transcription of the Gesamtkunstwerk can be found in Richard Wagner's concept of drama which was crystallized just after the 1848 Revolution (at that

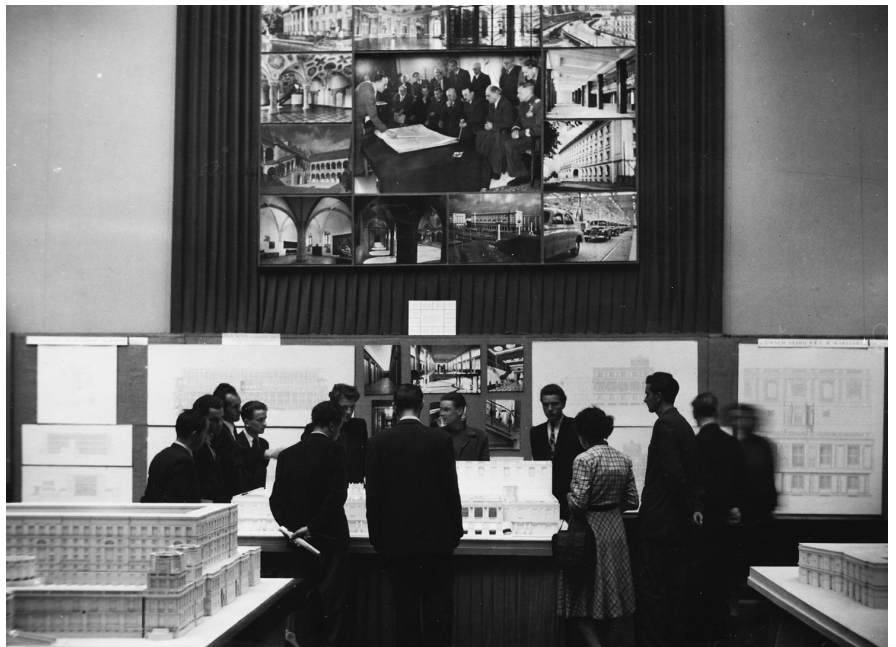

Figure 5. $1^{\text {st }}$ Exhibition of Architecture of the People's Poland, 1953. Photo: Zachęta - National Gallery of Art, Warsaw

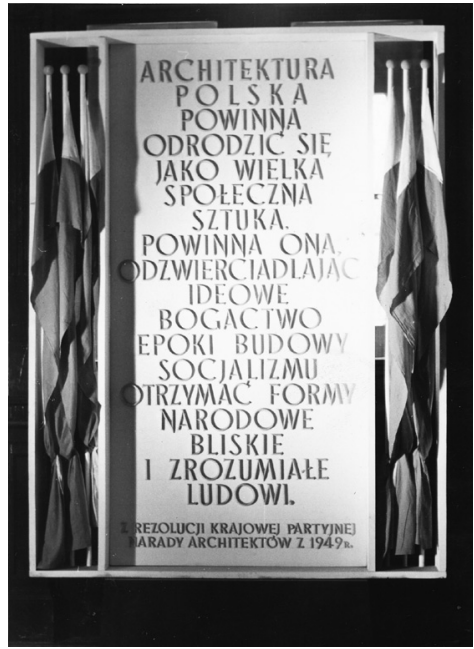

Figure 6. $1^{\text {st }}$ Exhibition of Architecture of the People's Poland, 1953.

Photo: Zachęta - National Gallery of Art, Warsaw 
time Wagner was in Dresden and befriended Mikhail Bakunin). As Carl E. Schorske aptly puts it: 'Like Schiller and Hegel, Hölderlin and Marx, Wagner saw the Greek polis as a historical archetype of community, a lost paradise to be regained. [...] The Greek polis and the Greek drama rose and fell together. When the polis fell, the drama fragmented into the many arts which had composed it $[\ldots] \cdot{ }^{38}$ It was the failure of the 1848 Revolution that brought Wagner to the idea of aesthetic community, the perfect reconcilement of art and life', and 'free artistic fellowship'. ${ }^{39}$ Wagner's own failure was that his romantic dream of aesthetic community, as expressed in his essays Die Kunst und die Revolution and Das Kunstwerk der Zukunft, turned into the community of aesthetes in Bayreuth. The line of further transcriptions (for example, from the theory of musical drama to the theory and practice of architecture) is too long to be discussed here in detail. Let us only mention William Morris and the Arts \& Crafts movement, or Adolphe Appia's essay Living Art-Work, published in 1919, the same year as the aforementioned Walter Gropius's Program of the Staatliches Bauhaus in Weimar.

The concluding question, however, is - where in this line of Gesamtkunstwerk transcriptions - can we place the idea expressed in the 1953 Warsaw exhibition, the idea of 'architecture that should be reborn as a great social art'. Searching for social aspects in the architectural politics of the time of Stalinism does not mean that I am an advocate, either of architectural utopias or of political terror. But, in a similar way, Rancière explains his reflection on the aesthetic regime of art:

My inquiry into the constitution of the aesthetic regime of art which has often been suspected of proposing a return to the fairy times and fairy tales of aesthetic utopias and aesthetic community, which either have brought about the big disasters of the $20^{\text {th }}$ century or, at least, are out of step with the artistic practices and political issues of the $21^{\text {st }}$ century. I tried to suggest that, on the contrary, this inquiry points to the tensions and contradictions which at once sustain the dynamic of artistic creation and aesthetic efficiency and prevent it from ever fusing in one and the same community of sense. The archaeology of the aesthetic regime of art is not a matter of romantic nostalgia. Instead I think that it can help us to set up in a more accurate way the issue of what art can be and can do today. ${ }^{40}$

Taking a lesson from Rancière one may also try to avoid the contemporary temptation for condemning all the collective efforts of socialist architecture as 'totalitarian'or 'Stalinist'. Thinking of architecture in terms of providing everybody with an affordable home or with public transportation is today 
often overshadowed by the principles of the neoliberal market which promotes corporate skyscrapers and luxury apartments. The aggressive gentrification methods employed by building developers in the neoliberal era were clearly expressed in a huge banner hanging in 2012 on the Warsaw Cosmopolitan apartment tower: 'Move Downtown. See What Others Cannot'. Let us take a lesson from Rancière and think about the social consequences of the distribution of the sensible in the realm of architecture. Regime of Art.” Art \& Research: A Journal of Ideas, Contexts and Methods 2/1 (2008): 4. (Warszawa: Zachęta, 1953), 13. prof. J. Zachwatowiczem," Stolica 13 (29th April 1953): 8. 
Ibid.

See: "O architekturę godną naszej epoki," Kurier Codzienny 93 (10-20th April 1953).

Roman Piotrowski [Wstęp], in I Powszechna Wystawa Architektury Polski Ludowej, 7-8.

'Odpowiadamy na pytania w sprawie Powszechnej Wystawy Architektury'.

See: Andrew Leach, John Macarthur, eds., Architecture, Disciplinarity, and the Arts (Ghent: A\&S Books, 2009); Gabriela Świtek, Gry sztuki z architektura. Nowoczesne powinowactwa $i$ wspólczesne integracje (Toruń: Wydawnictwo Naukowe Uniwersytetu Mikołaja Kopernika, 2013), 103-133.

Artur Żmijewski, "Polityczne gramatyki obrazów," in Jacques Rancière, Estetyka jako polityka, trans. Julian Kutyła, Paweł Mościcki (Warszawa: Wydawnictwo Krytyki Politycznej, 2007), 13.

See: Medium Specificity and Discipline Crossovers in Modern Art: An Interview with Jacques Rancière. http://thesip.org/2011/09/interview-with-jacques-ranciere [access: 30.04.2013]

Jacques Rancière, "The Distribution of the Sensible," in The Politics of Aesthetics, trans. Gabriel Rockhill (New York: Continuum, 2004), 15. See also Rancière, Aisthesis: Scenes from the Aesthetic Regime of Art, trans. Paul Zakir (London: Verso, 2013), 133-154.

Slavoj Žižek, "The Lesson of Rancière," in Rancière, The Politics of Aesthetics, 69-79.

Rancière, The Politics of Aesthetics, 60.

Jacques Rancière, "Powierzchnia designu," in Estetyka jako polityka, 113.

Ibid.

Rancière,"The Politics of Aesthetics," 52.

Ibid., 22.

See: Dalibor Vesely, Architecture in the Age of Divided Representation: The Question of Creativity in the Shadow of Production (Cambridge MA-London: The MIT Press, 2004), 366-367.

'The return of symbolism is obviously on the agenda. When I use this term, I am not referring to the spectacular forms of revival of symbolist mythology and the dream of the Gesamtkunstwerk, as in the work of Matthew Barney. [...] I am referring to the more modest, almost imperceptible way in which the collections of objects, images and signs gathered in our museums and galleries are increasingly shifting from the logic of dissensus to the logic of mystery, to a testimony of co-presence'. See: Jacques Rancière, "Contemporary Art and the Politics of Aesthetics," in Communities of Sense: Rethinking Aesthetic and Politics, eds. Beth Hinderliter, William Kaizen, Vered Maimon, Jaleh Mansoor, Seth McCormick (Durham-London: Duke University Press, 2009), 48. Jacques Rancière, ”The Emancipated Spectator," Artforum XLV (March 2007), 280. Medium Specificity and Discipline Crossovers in Modern Art: An Interview with Jacques Rancière. http://thesip.org/2011/09/interview-with-jacques-ranciere [access: 30.04.2013] Rancière, "The Politics of Aesthetics," 27. 'I am now convinced that the highest act of reason, encompassing all ideas, is an aesthetic act, and that truth and goodness come together only in beauty - the philosopher must possess just as much aesthetic power as the poet'. See: Friedrich Wilhelm Joseph von Schelling, "Das Älteste Systemprogramm des Deutschen Idealismus," in Briefe und Dokumente 1775-1809, ed. Horst Fuhrmans, vol. I (Bonn: H. Bouvier, 1962), 70. The authorship of this remark is not certain (see: ibidem, note 34, p. 69). For the English translation and interpretation of this particular phrase see: Thomas McFarland, Romanticism and the Forms of Ruin: Wordsworth, Coleridge, and Modalities of Fragmentation (Princeton, NJ: Princeton University Press, 1981), 48; Gabriela Świtek, Writing on Fragments: Philosophy, Architecture, and the Horizons of Modernity (Warsaw: Warsaw University Press, 2009), 48 and 56. 
Polski Ludowej, 2. See also: Marek Sadzewicz, "Architektura wielką sztuką społeczną," Stolica 10 (8th March 1953), 8-9.

Boris Groys, Gesamtkunstwerk Stalin (München-Wien: Carl Hanser, 1988); Boris Groys, The Total Art of Stalinism, trans. Charles Rougle (Princeton: Princeton University Press, 1992). See also: David Roberts, The Total Work of Art in European Modernism (Ithaca, NY: Cornell University Press, 2011).

Žižek, "The Lesson of Rancière," in Rancière, The Politics of Aesthetics, 77.

Ibid., 78.

'The aesthetic revolution as I have defined it first means that the former equation of the artwork with a specific place and destination was replaced by the idea of the framing of a specific sensorium or a specific sphere of experience. This specific sensorium can be the museum - viewed as the "remote" place where artworks are disconnected from their social or religious destination [...]'. Medium Specificity and Discipline Crossovers in Modern Art: An Interview with Jacques Rancière. http://thesip.org/2011/09/interview-with-jacques-ranciere [access: 30.04.2013] Świtek, Gry sztuki z architektura. Nowoczesne powinowactwa i wspótczesne integracje, 173-198. Carl E. Schorske, Thinking with History: Explorations in the Passage to Modernism (Princeton, NJ: Princeton University Press, 1998), 96.

Richard Wagner, The Art-Work of the Future and Other Works, trans. W. A. Ellis (Lincoln: University of Nebraska Press, 1993), 73.

Rancière, 'Aesthetic Separation, Aesthetic Community: Scenes from the Aesthetic Regime of Art', 14.

I Powszechna Wystawa Architektury Polski Ludowej, exhibition catalogue. Warszawa: Zachęta, 1953.

Conrads, Ulrich ed. Programs and Manifestoes on Twentieth-Century Architecture. Translated by M. Bullock. Cambridge, MA: The MIT Press, 1970.

Gawlowski, Stefan. "Wystawa Architektury w »Zachęcie«." Stowo Powszechne 63 (14-15 March 1953).

Groys, Boris. Gesamtkunstwerk Stalin. München-Wien: Carl Hanser, 1988.

Groys, Boris. The Total Art of Stalinism. Translated by Charles Rougle. Princeton: Princeton University Press, 1992.

Hinderliter, Beth and William Kaizen, Vered Maimon, Jaleh Mansoor, Seth McCormick, eds. Communities of Sense: Rethinking Aesthetic and Politics. Durham-London: Duke University Press, 2009.

Leach, Andrew and John Macarthur, eds. Architecture, Disciplinarity, and the Arts. Ghent: A\&S Books, 2009.

[Mar], "O architekturę godną naszej epoki." Kurier Codzienny 93 (10-20thApril, 1953).

McFarland, Thomas. Romanticism and the Forms of Ruin: Wordsworth, Coleridge, and Modalities of Fragmentation. Princeton, NJ: Princeton University Press, 1981. 
Medium Specificity and Discipline Crossovers in Modern Art: An Interview with Jacques Rancière. http://thesip.org/2011/09/interview-with-jacques-ranciere

"Odpowiadamy na pytania w sprawie Powszechnej Wystawy Architektury.” Stolica 21 (24th May 1953).

Rancière, Jacques. "Aesthetic Separation, Aesthetic Community: Scenes from the Aesthetic Regime of Art." Art \& Research: A Journal of Ideas, Contexts and Methods 2/1 (Summer 2008), 1-15.

Rancière, Jacques. Aisthesis: Scenes from the Aesthetic Regime of Art, trans. Paul Zakir. London: Verso, 2013.

Rancière, Jacques. "The Emancipated Spectator.” Artforum 45 (March 2007), 271-280.

Rancière, Jacques. Estetyka jako polityka, trans. Julian Kutyła, Paweł Mościcki. Warszawa: Wydawnictwo Krytyki Politycznej, 2007.

Rancière, Jacques. The Politics of Aesthetics, trans. Gabriel Rockhill. New York: Continuum, 2004.

"Regionalizm w architekturze. Rozmowa z patronem działu historycznego prof. J. Zachwatowiczem." Stolica 13 (29th April 1953), 8.

Roberts, David. The Total Work of Art in European Modernism. Ithaca, NY: Cornell University Press, 2011.

Sadzewicz, Marek. "Architektura wielką sztuką społeczną.” Stolica 10 (8th March 1953).

Schelling, Friedrich Wilhelm Joseph von. "Das Älteste Systemprogramm des Deutschen Idealismus." In Briefe und Dokumente 1775-1809, ed. Horst Fuhrmans, vol. I. Bonn: H. Bouvier, 1962.

Schorske, Carl E. Thinking with History: Explorations in the Passage to Modernism. Princeton, NJ: Princeton University Press, 1998.

Świtek, Gabriela. Gry sztuki z architekturą. Nowoczesne powinowactwa i wspótczesne integracje. Toruń: Wydawnictwo Naukowe Uniwersytetu Mikołaja Kopernika, 2013.

Świtek, Gabriela. Writing on Fragments: Philosophy, Architecture, and the Horizons of Modernity. Warsaw: Warsaw University Press, 2009.

Tyrmand, Leopold. Zly. Warszawa: Prószyński i S-ka, 2004.

Vesely, Dalibor. Architecture in the Age of Divided Representation: The Question of Creativity in the Shadow of Production. Cambridge MA-London: The MIT Press, 2004.

Wagner, Richard. The Art-Work of the Future and Other Works, trans. W. A. Ellis. Lincoln: University of Nebraska Press, 1993.

"Wystawa Architektury Polski Ludowej." Express Wieczorny 61 (11th March 1953). 


\section{BAUHAUS TEATAR - OSKAR ŠLEMEROV KONCEPT DIZAJNA U POKRETU}

\section{Sanela Nikolić}

Bauhaus Teatar je dobio svoju najpotpuniju formu kroz umetnički, pedagoški i teoretski rad Oskara Šlemera. Ključni problem za Šlemera je bio zakon kretanja ljudskog tela u prostoru. Njegova poetika je podrazumevala antinarativno i antimimetičko pozorište i isto tako široko rasprostranjenu upotrebu scenskih figura uz živopisnu artikulaciju prostora kao svoje primarne namene. Ljudsko telo na sceni, pretvoreno u artificijelnu figuru, je bilo univerzalni simbol ljudskog bića definisanog suprotnostima, koje postoji u geometrijski datom prostoru i određuje ga metafizički. Upotreba termina ,,igra“ u većini naslova Šlemerovih komada je u skladu sa koncepcijom scenskog događaja kao scenske igre artificijelne figure u geometrijski određenom prostoru, Koncept dizajn-u pokretu, što znači organizacija scene sa specifično mehaničkim-koreografskim kretanjima i rad sa formom i bojom, određuje Šlemerovu scenu kao apsolutnu vizuelnu scenu. U okviru Bauhausa, scenski rad Oskara Šlemera je doprineo razumevanju pozorišnog događaja kao podjednako značajne oblasti umetničkog dela za dizajn celine prostora u kojoj je uspostavljen skald između čoveka, njegovog životnog procesa i okruženja u kome čovek postoji.

KLJUČNE REČI: BAUHAUS TEATAR,SSKAR ŠLEMER, KONCEPT DIZAJNA-U-POKRETU, VIZUELNA SCENA, MEHANIČKI/METAFIZIČKI, LJUDSKO TELO U PROSTORU, ARTIFICIJENA FIGURA, TRIADSKI BALET

\section{ARHITEKTURA KAO POLITIKA}

\section{Gabriela Świtek}

Ovaj rad prikazuje komentar o razmišljanju Žak Ransijera o arhitekturi kako je skicirano u Politici Estetike i postavljeno pored studije slučaja - 1. Izložba Arhitekture Narodne Poljske. Izložba koja je organizovana u eri Staljinizma (1953) i prikazana u Centralnom Birou za Umetničke Izložbe (današnja Zacheta (Zaheta) - Nacionalna Galerija umetnosti u Varšavi) je viđena kao maninifestacija "umetničkih režima" iz tog perioda i kao estetizacija arhitekture koja se obično smatra naj "političkijom" od svih (lepih) umetnosti. Izgleda da arhitektura nije glavno razmatranje Politike Estetike, većina prevodilaca i (Poljski) komentatori Ransijerovih filozofskih spisa skreću nam pažnju na značaj njegove estetike za odnosne aspekte savremene umetnosti u javnim prostorima. Članak ima za cilja isticanje arhitektonkih trenutaka u Ransijerovon projektu estetike kao politike, on isto tako razrađuje nekoliko pojmova poiēsis/ mimēsis - kao što je rečeno od strane Ransijera - u odnosu na arhitektonsku teoriju i istoriju arhitektonskih izložbi.

KLJUČNE REČI: ARHITEKTONSKE IZLOŽBE, ESTETSKA ZAJEDNICA, DISTRIBUCIJA RAZUMNOG, GESAMTKUNSTWERK, MULTIMEDIJALNOST, SOCREALIZAM, TOTALITARIJANIZMI

\section{ARHITEKTURA I MUZIKA/ZVUK: \\ TAČKE SUSRETANJA, UMREŽAVANJA, SADEJSTVA}

\section{Biljana Srećković}

Ovaj tekst posvećen je sagledavanju odnosa između muzike i arhitekture, odnosno diskursa koji interpretiraju, istražuju, vrednuju ove dve prakse u kontekstu njihovog međusobnog umrežavanja. U vezi sa tim, moguće je izdvojiti nekoliko problemskih uporišta koji će biti u fokusu ovog rada, a tiču se: istorije formiranja i evolucije diskursa o međusobnom odnosu ove dve prakse; modernističke, avangardističke i postmodernističke problematizacije muzike i arhitekture; teorije umetnika kao polja umrežavanja muzike i arhitekture; interakcije muzike i arhitekture na tehničkom i formalnom nivou; prostronosti zvuka, tj. prostiranja zvuka/muzike u prostoru i pojave novih umetničkih koncepata zasnovanih na ovom principu (sound architecture, aural arhitecture, sound art). 